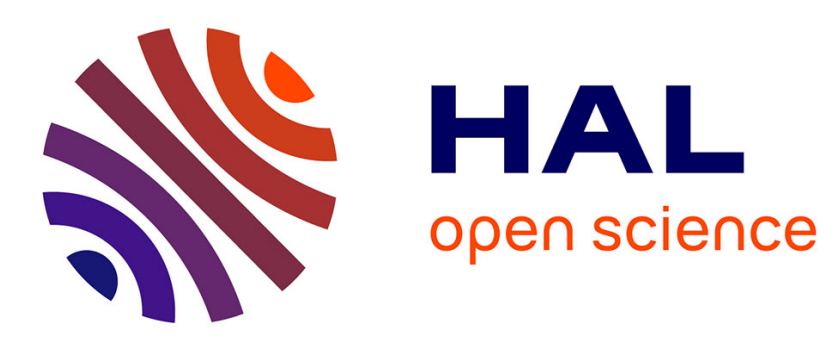

\title{
High-pressure Adaptation of Extremophiles and Biotechnological Applications
}

\author{
M. Salvador Castell, P. Oger, Judith Peters
}

\section{To cite this version:}

M. Salvador Castell, P. Oger, Judith Peters. High-pressure Adaptation of Extremophiles and Biotechnological Applications. Physiological and Biotechnological aspects of extremophiles, inPress. hal02122331

\section{HAL Id: hal-02122331 \\ https://hal.science/hal-02122331}

Submitted on 4 Nov 2020

HAL is a multi-disciplinary open access archive for the deposit and dissemination of scientific research documents, whether they are published or not. The documents may come from teaching and research institutions in France or abroad, or from public or private research centers.
L'archive ouverte pluridisciplinaire HAL, est destinée au dépôt et à la diffusion de documents scientifiques de niveau recherche, publiés ou non, émanant des établissements d'enseignement et de recherche français ou étrangers, des laboratoires publics ou privés. 


\section{Applications}

$4 \quad{ }^{1}$ Univ Lyon, INSA de Lyon, CNRS, UMR 5240, F-69621 Villeurbanne, France.

$5 \quad 2$ Université Grenoble Alpes, LiPhy, F-38044 Grenoble, France.

$6 \quad{ }^{3}$ Institut Laue Langevin, F-38000 Grenoble, France.

7

$8 \quad *$ corresponding authors

$9 \quad$ J. Peters: peters@ill.eu

10 Pr. Judith Peters, Institut Laue Langevin, 71 Avenue des Martyrs, CS 20156, 38042 Grenoble cedex 09

11 tel: $33-476207560$

12

13 P.M. Oger : philippe.oger@insa-lyon.fr;

14 Dr Phil M. Oger, UMR 5240 MAP, INSA de Lyon, 11 avenue Jean Capelle, 69621 Villeurbanne cedex.

15

tel: 33-4 72436001

16

17

18 
Applications

$21 \quad$ Abstract (about 150 words)

22 During the last decades, high pressure has been an important physical parameter not 23 only to study biomolecules, but also for its biotechnological applications. High pressure 24 affects organism's ability to survive by altering most of cell's macromolecules. These 25 effects can be used, for example, to inactivate microorganisms, enhance enzymatic 26 reactions or to modulate cell activities. Moreover, some organisms are capable to 27 growth under high pressures thanks to their adaptation at all cellular levels. Such 28 adaptation confers a wide range of potentially interesting macromolecules still to be 29 discovered. In this chapter, we firstly present the different effects of pressure on cells 30 and the diverse strategies used to cope against this harsh environment. Secondly, we 31 explored the pressure biotechnological applications on pressure-sensitive and adapted32 pressure organisms.

\section{Introduction}

37 High pressure (HP) characterizes many habitats on Earth, such as deep sea, sub sea floor 38 and continental subsurface. Ocean covers approximately $70 \%$ of world's surface and its average pressure is $38 \mathrm{MPa}(1 \mathrm{MPa}=10 \mathrm{bar})$. This hydrostatic pressure originates from the weight of the water column and corresponds to $10 \mathrm{MPa} / \mathrm{km}[1]$. Part of the oceans are defined as "deep sea", which encompasses the entire biosphere below $1000 \mathrm{~m}$ from 
42 the water surface and consequently with pressure higher than $10 \mathrm{MPa}$. The highest

43 hydrostatic pressure detected in the ocean is approximately $110 \mathrm{MPa}$ at $11,000 \mathrm{~m}$ depth

44 at the Challenger Deep of Mariana Trench in the Pacific Ocean. Though, pressures

45 above $110 \mathrm{MPa}$ have been found at the sub sea floor. In this case, pressure is caused by

46 hydrostatic pressure but also by the weight of material (lithostatic pressure) and it

47 increases roughly by $15 \mathrm{MPa} / \mathrm{km}$ in sediments and by about $28 \mathrm{MPa} / \mathrm{km}$ in oceanic

48 rocks. Sub sea floor contains a substantial part of the Earth biomass and can potentially

49 influence global biochemistry [2-4].

50 All high-pressure habitats are occupied by microorganisms and other complex 51 organisms and they highly contribute to the Earth's biomass [5,6]. Pressure impact on 52 organisms' growth allow to divide them in different categories. Organisms that cannot 53 tolerate ambient pressure are designed as strict or obligate piezophiles, inversely, 54 facultative piezophiles or just piezophiles are organism that tolerates ambient pressure, 55 but their optimal growth pressures are higher than $10 \mathrm{MPa}$ (figure 1). On the other side, 56 organism that withstand optimal pressures lower than $10 \mathrm{MPa}$ are called piezotolerants 57 and, finally, organisms which their growth is inhibited by pressure are designed as 58 piezosensitive [7]. 


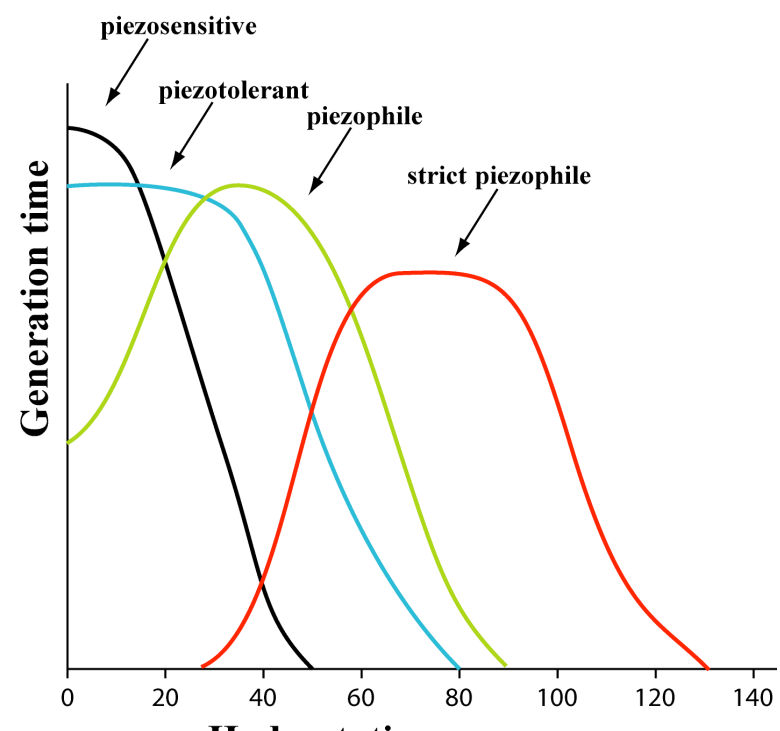

Figure 1. Schematic growth curves of microorganisms according to pressure (MPa) [7].

61 The interest in piezophiles has begun more than a century ago[8,9], but the

62 technological difficulties and the need of specialized equipment have done that high-

63 pressure studies are not, currently, developed in most laboratories. However, the interest

64 and the applications of the pressure biotechnological applications have been growing 65 during last decades.

66 Bacteria and Archaea domains contain facultative and obligate piezophiles. Examples of

67 obligate piezophiles are the bacteria Shewanella benthica and Colwellia marinimaniae,

68 with their optimal pressure at $70 \mathrm{MPa}$ and $120 \mathrm{MPa}$ respectively $[10,11]$, and the 69 archaeon Pyrococcus yayanossi, withstanding an optimal pressure of $50 \mathrm{MPa}$ [12]. The

70 technical constraints to isolate obligate piezophiles may provoke their underestimation.

71 Obviously, piezophiles excel in sustaining pressure conditions beyond the usual limits

72 for humans; however, the reasons for that adaptation are still debated.

\section{Effects of Pressure on Macromolecules and Cells}

74 Pressure alters the biomolecules by changing their volume. Thermodynamically, the variation in Gibbs free energy $(G)$ is defined by the equation 1 
77 where $\Delta \mathrm{S}$ is the difference in entropy, $\Delta \mathrm{V}$ the change in volume and $\mathrm{T}$ and $\mathrm{P}$ represent 78 temperature and pressure, respectively. At constant temperature, dT $=0$ and thus

$$
\left(\frac{\partial G}{\partial P}\right)_{T}=\Delta V
$$

This equation, according to the Le Chatelier principle [13], states that an increase in pressure will cause a shift to the state that occupies the smallest volume, meaning, for example, to the unfolded state for most globular proteins, where $\Delta \mathrm{G}<0$. As a result, pressure modifies the volume of the system but not its internal energy (as temperature does). Water with its low compressibility is a crucial partner for pressure action. Notably hydration water (water bound at the surface of macromolecules) is very sensitive to pressure and it can reorganize its network under pressure implying an effect on the macromolecule[14]. Moreover, macromolecules present an extraordinary stability against pressure under low hydration conditions $[15,16]$.

Relatively low pressures affect the interatomic molecular bindings (such as Van der Waals, hydrogen bonding and hydrophobic interactions) altering conformations and structures of biomolecules and therefore, their physical properties (solubility, melting point, density), equilibrium states and processes' rate [17]. Electrostatic and hydrophobic interactions are specifically affected by pressure. In contrast, pressures above $2 \mathrm{GPa}$ are needed to impact non-covalent interactions $[18,19]$.

\subsection{Nucleic acids}

Although the unfolding volume of DNA duplexes is small, pressures up to $1 \mathrm{GPa}$ have, in general, a stabilizing effect on canonical DNA (e.g. with common pair bases). This stabilizing effect may be explained by the decrease of hydrogen bonds' distance. 
99 Consequently, pressure increases the duplex-single-strand transition temperature[20].

100 Only in specific cases of synthetic polymers ( e.g adenine - thiamine copolymer) and 101 salt concentrations, pressure can lead to double-stranded melting [21]. Regardless, the 102 mechanism is not the same as the heat-induced DNA melting, as under pressure, water 103 molecules penetrate DNA base pairs destabilizing their interactions [22,23].

104 There is a lack of information about the effect of pressure on RNA but, generally, it has 105 been observed that RNA is more pressure sensitive than DNA. For example, pressure 106 induces a structure reorganization of tRNA [24,25] and it destabilizes small RNA 107 oligomers [26].

108 Non-canonical pair structures (different from the usual Watson-Crick pair bases), such 109 as G-quadruplexes or stem-loops, are less stable under pressure than canonical 110 structures by a factor of $10[22,27]$.

111 Although canonical DNA duplexes are stabilized by pressure, DNA-protein 112 interactions may be perturbed due to changes in the electrostatic and hydrophobic 113 interactions. Accordingly, pressure affects negatively all molecular reactions where 114 DNA is involved, such as replication, transcription and recombination $[28,29]$.

\subsection{Proteins}

116 Most of the knowledge about pressure effects on proteins is based on studies on 117 globular proteins[30-32]. Some of these studies reveal that structural transitions of 118 globular protein due to pressure are based on a hydration mechanism that accompanies 119 protein conformational changes. At higher pressure the hydration degree is increased by the penetration of water into the protein cavities causing the increase of the surface area 121 in contact with the solvents thus contributing to the volume change[33]. Pressure mainly 122 alters tertiary and quaternary structures of proteins but secondary structures ( $\alpha$-helices, 
$123 \quad \beta$-sheets, and turns) are much less sensitive to water penetration and to destabilization 124 by pressure. For this reason, the state unfolded by pressure may be a hydrated globular 125 structure with large amounts of folded structure[17,34]. It is important to note again the 126 role of water on pressure denaturation, since this volume change can only be observed 127 for proteins in solution. Dry proteins are highly stable against pressure[18,35,36].

128 The unfolding of many monomeric proteins begins above $200 \mathrm{MPa}$ [4], however 129 enzymatic activities are usually modified at lower pressures. In fact, the application of 130 pressures $<200 \mathrm{MPa}$ confers higher thermostability to most proteins [35,37]. 131 Consequently, superposing pressure and temperature usually accelerates most of 132 enzymatic reactions, such as hydrolases and transferases reactions [36]. Moreover, few reactions can be enhanced by pressure even at low temperatures [36]. For example, the 135 increased at $300 \mathrm{MPa}$ [38].

136 Pressure generally changes the equilibrium between oligomers and their subunits or between two different proteins and this even at relative low pressures (about $50 \mathrm{MPa}$ ) [39]. At this pressure, for example, ribosomes' subunits are dissociated [29] and larger protein assemblies as cytoskeletal proteins are disturbed resulting in reversible morphological changes [40]. However, other oligomers are more resistant to pressures as the tetrameric urate oxidase, which dissociates at about 150-175 $\mathrm{MPa}$ [41].

142 Actually, a protein in its native state possesses distinct, nearly isoenergetic 143 conformational substates, which may have similar or dissimilar functions or the same 144 function with different rates (statistical substates). As pressure can decrease the folding 145 rate and increase the unfolding one, it can shift the population of different protein substates on the basis of their volumetric differences [42-44]. This capability allows the 147 characterization of various intermediate substates by pressure, which may act in the 
folding process [45]. Moreover, pressure can change the reaction rates, providing new information about the dynamics and reactions of proteins [34]. This was confirmed, for example, by a dynamic study of myoglobin, where it has been shown that pressure reduces protein motions and facilitates access to different substates [44].

152 Few studies have been done on pressure effects of non-globular proteins, as fibrous, 153 disordered and membrane proteins. Examples are the studies on the collagen structure 154 [46], the intrinsically disordered protein alpha synuclein [47] and on the Lmr 155 transmembrane protein [48] or the ion channel MscS [49]. An important point is that the 156 behaviour of transmembrane proteins against environmental stresses is affected by the 157 protein structure but also by its lipids surrounding [50].

158 Membrane proteins and membrane lipids form an ensemble; they influence each other as a result of biochemical or environmental changes which can compromise membrane process as energy production or ion flux. For example, the transporter efficiency of the tryptophan permease Tat 2 from yeast cells is affected due to a membrane fluidity modification at HP[51]. Therefore, membrane integrative studies are necessary to better describe the membrane protein behaviour. Its influence of the lipid matrix on the protein response to pressure have been studied for few proteins [52-54].

Lipids, and specially their hydrocarbon chains, possess a highly compressible potential, which makes them very sensitive to pressure [55]. When pressure is applied on a phospholipid bilayer, the acyl chains from phospholipids get straighten resulting in a thicker and higher ordered bilayer. Due to this higher acyl chains' order, pressure promotes the lipid phase transition from liquid-crystallin (phase essential for the biological function of the membrane) to a more rigid phase called the gel phase. 
172 Additionally, pressure can also promote the apparition of new phases, such as 173 interdigitated phases or non-lamellar phases (i.e., cubic or hexagonal)[55-59].

174 Nevertheless, not all lipids have the same sensitivity to pressure, for example, lipids

175 with longer hydrophobic chains are more responsive to pressure. This may result in a

176 phase separation in domains on model membranes from a mixture of lipids[60].

177 Pressure may have also an impact on more complex macromolecules, as lipoproteins.

178 Recent studies on human plasma lipoproteins under HHP revealed a reduced flexibility 179 and higher compressibility of its triglyceride rich form, the form associated to 180 pathological health conditions $[61,62]$.

\subsection{Cells}

182 Surprisingly, pressure is the unique physical parameter capable of inducing heat-shock 183 and cold-shock proteins' as a cell response to a same stress. Escherichia coli (E. coli) 184 exposed to $53 \mathrm{MPa}$ induces 55 proteins, 11 heat-shock and 4 cold-shock proteins among them. E. coli may try to counteract the damage produced by pressure at different cell 186 levels, such as stability of macromolecules and membrane functionality[63].

187 As mentioned, pressures up to $100 \mathrm{MPa}$ affects most of the cellular functions as 188 enzymatic reactions, gene expression, cell motility and morphology, and cell membrane 189 (figure 2). Since pressure is transmitted through a fluid, it will be transmitted uniformly 190 (Pascal's law) over the whole cell and therefore, it makes difficult to identify, if it 191 exists, the main cause of the cell death. Moreover, pressure-induced cell inactivation 192 relies on the type of microorganism and its physiological conditions, such as water 193 content and salt presence.

194 Overall, eukayotes are more pressure-sensitive than prokaryotes and piezosensitive bacilli and spiral-shaped bacteria are inactivated at lower pressures than cocci $[39,64]$. 
196 For instance, pressures above $150 \mathrm{MPa}$ usually reduces the viability of mammalian cells 197 and may induce cell death by apoptosis from $200 \mathrm{MPa}$ or through a necrotic-like 198 pathway at $300 \mathrm{MPa}$ [65]. On the other hand, bacteria cocci may resist much higher 199 pressure variations, for example, Staphylococcus aureus cell inactivation begins at 350 $200 \quad \operatorname{MPa}[64]$ 

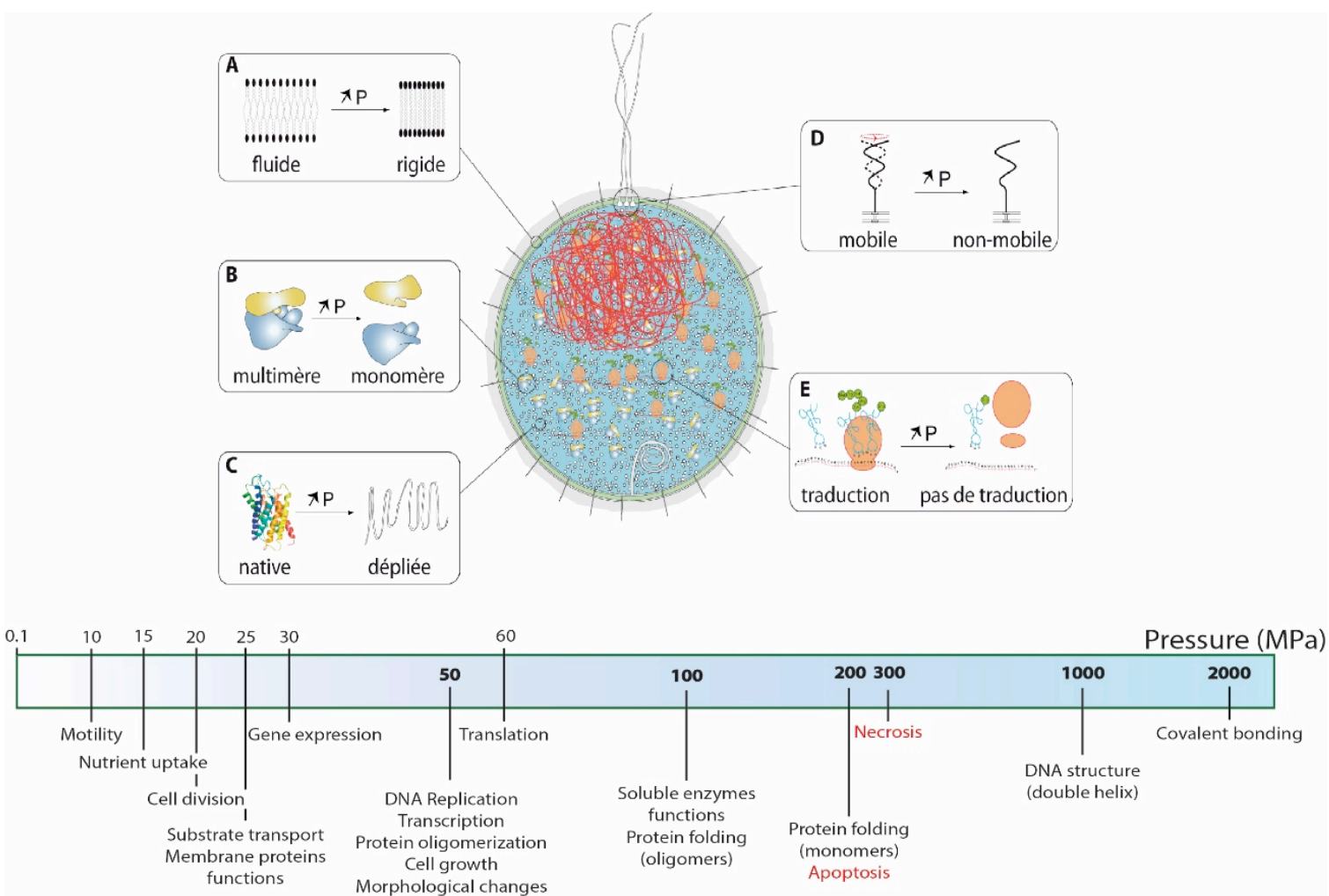

203 Figure 2. General effects of pressure on cellular macromolecules (black) and cells (red). Adapted from [66]

204 In addition, most gram-negative bacteria seem to be less resistant to pressure than gram205 positive [67]. Gram-negative bacteria possess a much more complex membrane which 206 makes it a target for pressure damage [68]. Finally, microorganisms on the exponential 
growth phase present lower pressure-tolerance than on their stationary growth phase[69,70], for example, exponential-cells may present filamentous shape under

209 pressure which can disrupt membrane functions [29,71]. Moreover, stationary-cells

210 have the capability to synthesize stress-response proteins to adapt and, therefore, better

211 resist to different harsh conditions[72].

212 Spores present formidable high resistivity to harsh environments, likely due to their 213 structure with numerous protective layers and their low water content [73].

214 Interestingly, relative moderate pressures (50 to $300 \mathrm{MPa}$ ) cause the germination of a 215 dormant spore. Though, higher pressures are often less effective to induce 216 germination[74]. Pressure alone is not very effective to inactivate bacterial spores and a 217 treatment with temperature is necessary[75].

The biodiversity of piezophiles is huge [5,76-78]. Organisms adapted to pressure 221 include unicellular bacteria, archaea, eukaryotes as invertebrates and fishes and even 222 deep diving marine mammals [79-81]. For example, in several hydrothermal vents have 223 been found large invertebrates like mussels, crabs and shrimps and some marine 224 mammals can dive exposed to almost $20 \mathrm{MPa}$ without any negative symptom $[82,83]$. 225 There are differences in the microorganisms adapted to HP, as some are also adapted to 226 low temperatures (psychrophiles) and others to high temperatures (hyperthermophiles), which increases the piezophilic diversity. Hyperthermophilic and piezophilic organisms are found near vent sites, where temperatures can go from $350{ }^{\circ} \mathrm{C}$ to $2^{\circ} \mathrm{C}$ in only few $\mathrm{cm}$ distances. Altogether, this represents a source of microorganisms with great potential 

cancer cell line active derivatives.

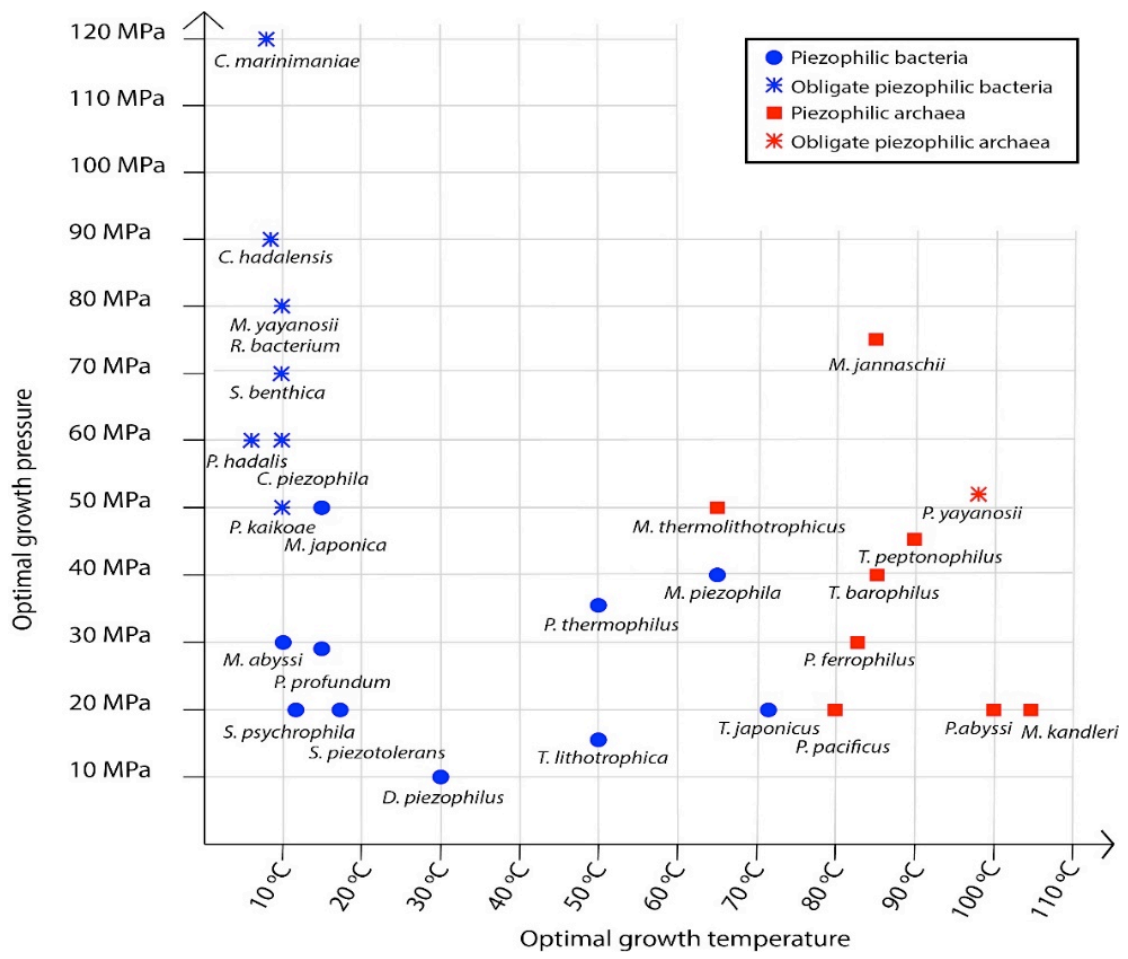

Figure 3. Optimal growth temperature and pressure for some piezophilic bacteria (blue) and archaea (red).

Most piezophiles identified in the deep sea are bacteria, they are psychrophiles and piezophiles, but in the niche of hydrothermal vents, most microorganisms are archaea, they are thermophiles and piezophiles [84] (figure 3). This indicates that piezophiles may follow a different adaptation to temperature and makes it difficult to separate the adaptation to pressure from other stress adaptation since microorganisms may adopted a common strategy to cope with various environmental stresses [85]. High pressure has a close relation with other stresses as temperature, $\mathrm{pH}$ and salt. Moreover, there are relatively few studies on adaptation mechanisms to pressure and not all adaptations are equally used by the different piezophiles studied. Additionally, not all necessary pressure adaptation mechanisms are deleted at ambient pressure, and therefore the homologue enzymes may use the same mechanism [66]. Finally, piezophilic biospheres 
245 are closely related to nutrient limitation and most piezophiles must also be oligotrophes [4].

247 Extremophiles have developed great capabilities to adapt to harsh and even fluctuating 248 conditions (e.g. temperature, pressure, composition of the host rocks...) thanks to their 249 own unique macromolecules, such as polysaccharides, lipids or enzymes and even specialized organs[86]. These macromolecules adapted to HP present a high potential to 251 develop new biotechnological applications.

\subsection{Genomes}

253 Marine biosphere contains mobile genetic elements, such as plasmids, bacteriophages, 254 transposons, integrons, integrative conjugative elements and genomic islands [87]. All 255 of them are essential to understand the high marine microbial diversification and 256 thereby their adaptation $[88,89]$. Consequently, horizontal gene transfer of these mobile 257 genetic elements may play an essential role in the microbial adaptation to pressure and 258 other extreme conditions [90].

259 Recently, it has been described that the gene Ypr153w is possibly responsible for the 260 tryptophan permease's Tat2 stability in Saccharomyces cerevisiae under pressure. It is a 261 gene which has also been identified in other related species as Debaryomyces and 262 Candida strains which have been isolated from sediment samples of deep sea floors 263 [91]. Another possible HP adaptation could be the 16s rRNA longer stems found in 264 strains from Photobacterium, Colwellia and Shewanella [92].

265 The high genetic tractability and hyper-responsiveness to pressure of the piezophile 266 Photobacterium profundum strain SS9 has made it a reference for studies on piezophile 267 adaptation. It has been discovered a pressure-sensitive mutant of SS9 that lacks the recD gene, responsible for a DNA-binding protein. Besides, the transfer of the recD gene 
269 from SS9 to E.coli enabled the latter one to divide normally under HP. This indicates

270 that RecD may have an important role for piezoadaptation together with a role of DNA

271 metabolism and cell division[93,94].

272 To date, it has not been possible to detect any piezospecific gene. Consequently, it is not

273 possible to determine if an organism is piezophile by molecular approaches, it is 274 necessary to do cultivation approaches and to determine the growth rates at different 275 pressures. However, it has been found that the pressure regulated operons ORFs 1-3 are 276 distributed among different piezophilic Shewanella species[95].

\subsection{Proteins}

278 Relatively few enzymes from piezophiles have been studied under pressure. Although 279 there are no apparent differences between the crystal structure of an enzyme from a 280 piezophile and its piezosensitive homologue, there is a variation in the stability between 281 both enzymes caused by a difference in flexibility and hydration of the proteins[96]. 282 Most molecular motion studies about pressure adaptation have been done in vitro, or 283 investigating, for example, molecular dynamics[97]. Nevertheless, nowadays in vivo 284 studies have gained importance thanks to, for example, neutron scattering and NMR 285 experiments that can examine timescales from few nanoseconds to hundreds of 286 milliseconds[98-100].

287 It has been shown that some proteins are involved in HP adaptation as well as in 288 adaptation to other stresses (Hsp60, Hsp70, OmpH, RecA, F1F0 ATPases, Cct and 289 Tat2)[101]. A system highly studied under pressure is the Omp/Tox system. The 290 proteins ToxS and ToxR from P. profundum SS9 are responsible for regulating the 291 genes that encode the membrane proteins $\mathrm{OmpH}, \mathrm{OmpL}$ and OmpI. Pressure reduces 292 the abundance and the activity of ToxR, which therefore upregulates the protein OmpH 
among others, the system acts as a piezometer. Regardless, the systems ToxS and ToxR do not confer HP adaptation and their role under pressure is not clear [8,102].

The protein adaptation to extreme conditions is a balance between the imperative stability (higher number of bounds) to be functional and the flexibility (lower number of bounds) to be capable to adapt to different conditions [103]. One of the most studied enzymes is dihydrofolate reductase (DHFR). Studies comparing DHFR from the piezosensitive E. coli and from the facultative psychro-piezophile bacteria Moritella profunda reveals that applying pressure decreases EcDHFR activity and increases MpDHFR activity up to $50 \mathrm{MPa}$ before diminishing its activity at higher HP. MpDHFR seems to have higher sensitivity to pressure due to its higher flexibility [104]. A more flexible protein may explain the higher absolute activity of piezophile proteins [105]. However, most of studies are done in protein-isolated solutions, which differs from their native state. An innovative quasi-elastic neutron scattering study examined the dynamics from whole cells of the piezophile Thermococcus barophilus and the piezosensitive Thermococcus kodakarensis microorganism under atmospheric pressure

311 Proteins from piezophiles may have a larger total volume of small internal cavities, which makes the protein more compressible and less sensitive to distortion caused by pressure [105]. Moreover, the presence of small cavities allows water penetration at HP and consequently increases the hydration but, as seen in MpDHFR, cavities are not big enough to cause the protein denaturation but allow the protein to be more flexible. The presence of more small cavities could decrease the amount of water molecules 

an increase of approximately $45 \mathrm{~A}^{3}$ is required for each extra molecule [106]). It is important to consider that cavities are not mere "packing defects" but that they play a role in conformational changes and in controlling binding and catalysis of the proteins

$321 \quad[106,107]$.

322 Generally, monomeric proteins are more resistant to pressure than oligomeric proteins.

323 However, it has been shown that multimeric proteins may be adapted to resist to 324 pressure. For example, studies on the hyperthermophile and piezophile TET3 peptidase 325 from Pyrococcus horikoshii indicate that the protein multimerizes into a dodecamer 326 structure instead of conserving its classical barrel-shape multimer conformation. 327 Dodecamer multimerization protects the hydrogen bonding between the different 328 subunits and increases its stability against temperature and pressure up to $300 \mathrm{MPa}$ $329 \quad[108]$

330 A general extrinsic cell response to pressure-stress is the presence of piezolytes and 331 other low weight organic compounds called osmolytes (e.g., sugars and amino acids) to 332 protect the cell macromolecules, such as proteins, from pressure modification [109] and 333 therefore adapt its dynamics. Some piezophiles accumulate these low-weight molecules 334 in response to an increase on pressure and others to a decrease, indicating in the latter 335 case that the growth at lower pressure than optimal is perceived as a stress for these 336 piezophiles. For example, trimethylamine oxide (TMAO) is a pressure co-solute that helps proteins to remain active under HP in certain fishes and crustaceans [80,110]. On 338 the other hand, the hyperthermophilic and piezophilic Thermococcus barophilus 339 accumulates mannosyl-glycerate when it is grown in non-optimal conditions (ambient 340 pressure) [111]. This indicates that this archaeon perceives the lack of pressure as a 341 stressful condition. 
342 Few studies have been done on pressure adaptation of higher complex pluricellular 343 organisms. For example, it is thought that the regulation of N-methyl-D-aspartate 344 receptor (NMDR), a cell membrane protein found in nerve cells, is responsible for the 345 absence of the high-pressure nervous syndrome (HPNS) on deep dive mammalians $346[83,112]$. The regulation of this protein may be done by modulating its interaction with 347 lipids, for example by the presence of cholesterol, and thanks to protein's particular 348 tertiary structure in piezo-tolerant organisms.

\subsection{Membrane lipids}

350 Cells have the capability to modify their cell membrane lipid composition metabolically 351 to maintain it in a functional liquid crystalline phase with specific functional 352 physicochemical properties, such as fluidity, permeability and membrane curvature in 353 spite of environmental stresses. This process is known as homeoviscous adaptation $354 \quad[113]$.

355 Eukarya and bacteria possess lipids different from those in archaea but their 356 homeoviscous adaptations have similarities. Eukaryal and bacterial lipids are composed

357 by straight hydrocarbon chains linked by ester bonds on 1,2 -sn- glycerol and a 358 phosphodiester-linked polar group or sugar. On the other hand, archaeal lipids have 359 isoprenoid hydrocarbon chains bounded by ether bonds on 2,3-sn-glycerol. Partly, the adaptation of archaea to extreme conditions may thus rise from their particular lipid 361 structure [114]. The common routes of lipid adaptation of bacterial and archaeal membranes are the change of the acyl chain length, the addition or removal of mono-unsaturated lipids and the change in the polar headgroups $[115,116]$. Longer acyl chains are translated into more rigid membranes, in contrary adding just one unsaturation to lipid chains makes 
366 the membrane more permeable and larger headgroups increase the disruption of the 367 membrane packing by increasing the membrane fluidity. Furthermore, archaea possess 368 tetraether lipids, which may form a monolayer instead of the common bilayer. In 369 addition, some archaeal species comprise lipids with cyclopentane rings and isoprenoid 370 chains that are crosslinked. The change in the different ratios from di- and tetra-ether 371 lipids and the presence of cyclopentanes and crosslinked chains modifies as well the 372 properties of the cell membrane. Finally, psychrophilic bacteria present polyunsaturated 373 fatty acids (PUFAs), such as eicosapentaenoic acid (EPA) and docosahexaenoic acid 374 (DHA), which, just as lipids with one unsaturation, increase the permeability of the 375 membrane under low temperatures[117]. The function of PUFAs is not clear, one of the 376 hypotheses is that requires less carbon and energy to obtain the same effect than the 377 mono-unsaturated lipids $[8,117,118]$. Another hypothesis is that they may play a role in 378 cell division under HP, as demonstrated for bacteria Shewanella violacea[119].

379 Only two studies have been done to examine the lipid composition under pressure: one 380 on Methanocaldococcus jannaschii and another on T. barophilus[120,121]. Both 381 present an increase in the diether : tetraether lipid ratio to counteract the increase in 382 rigidity provoked by pressure on the cell membrane. 


\section{Pressure Biotechnological Applications}

HP application is mostly used in food processing since it does not affect non-covalent interactions (at least up to $2 \mathrm{GPa}$ ) and it can inactivate bacteria and viruses without changing markedly nutrients and flavours of food. Furthermore, pressure can change the reaction rates, which may favour the extraction of the required product[19].

Besides, pressure may be used for diverse biotechnological and biopharmaceutical applications, for example to explore new therapies [122,123] and conserve vaccines [123], improve cryopreservation [125] or for orthopaedics' surgery [126].

\section{1. $\quad$ Food Industry}

HP (400 - $600 \mathrm{MPa})$ inactivates microorganisms, like yeast, molds and viruses. It affects the cell at different levels, such as nutrient transport and cell reproduction, reaching to the cell death $[75,127]$. Moreover, HP hardly affects low-molecular weight compounds (ex: vitamins, amino acids, flavour molecules) so, organoleptic and nutritional properties are only slightly modified [128]. On the other hand, HP alone cannot inactivate bacterial spores and thus a combination with other variations of $\mathrm{pH}$, chemicals or thermal processes maybe needed. Nevertheless, pressure reduces considerably the working temperature, as $70^{\circ} \mathrm{C}$ instead of $180{ }^{\circ} \mathrm{C}$ is enough to inactivate spores if it is combined with $600 \mathrm{MPa}$ [75]. Such decrease in temperature can help to preserve quality and minimise off-flavour generations. Therefore, HP techniques are useful as a complement on thermal process but also to inactivate microorganisms on products where temperature cannot be applied. As an illustration, high pressure pasteurization of cold-pressed juices eliminate pathogens of juices without impairment of its fresh-like qualities and increasing the shelf life of the product $[129,130]$. 
HP extends shelf life of a high variety of food products. For example, fresh shrimp treated at $435 \mathrm{MPa}$ has a shelf life of 15 days, three times longer than the shelf life of the untreated shrimp[131]. Fresh cheese treated at 300-400 MPa has a shelf life at $4{ }^{\circ} \mathrm{C}$ of 14-21 days, which is greatly higher than the 7 days for the untreated cheese[132].

Food is a complex matrix and inactivation efficiency depends on different factors as treatment conditions, microorganisms to inactivate and its food matrix characteristics. For example, meat treated at $300 \mathrm{MPa}$ has a cooked like appearance but if it is processed at $100-200 \mathrm{MPa}$ and $60{ }^{\circ} \mathrm{C}$, it is more tender than the untreated meat[133]. Consequently, inactivation conditions must be defined for every food product. HP is not efficient for low water content food (such as flour) or food with high content of air bubbles and if the food needs to be wrapped before treatment only plastic packaging is acceptable, as packaging material needs a compressibility of at least $15 \%$ [127].

Finally, HP may also be applied as a pre-treatment. On the one hand, it has been demonstrated that the application of sublethal HP on cells gives them cross-resistance to other stresses. For example, the most studied probiotic, Lactobacillus rhamnosus, is more resistant to heat after an application of $100 \mathrm{MPa}$ for $10 \mathrm{~min}[134]$. This opens the possibility to inactivate the pathogens on probiotic products, conferring a health benefit.

On the other hand, pre-treatment can be useful to facilitate the extraction of internal nutritional components. HP makes the cells more permeable, increasing the mass transfer rate and as a result incresing the release of extracts. It has been shown that the time extraction of caffeine from green tea leaves is reduced from $20 \mathrm{~h}$ to $1 \mathrm{~min}$ if a pressure of $500 \mathrm{MPa}$ is applied; extraction of anthocyanin red grape skin is increased by $23 \%$ by applying $600 \mathrm{MPa}$ of pressure and the extraction yield of gingenosides from Panax quinquefolium root increases linearly between $100 \mathrm{MPa}$ and $500 \mathrm{MPa}$ [135]. 
432 Several proteins can provoke allergic reactions caused by an immune disorder on the

433 IgE binding. Because HP tend to denature proteins and as a result, it has been shown to 434 induce a modification of their allergenicity[136], both on protein solutions and on food 435 systems. For example, pressures of 300-700 MPa reduce the allergenicity of a ginkgo seed protein and of soybean allergens[137]. Another interesting example is the use of

437 HP together with proteases to obtain hypoallergenic rice[138,139]. However, the effect

438 of HP on allergenicity is not universal. There is no allergenicity change caused by 439 pressure on almonds, or on the protein Mald1 from apples[140,141]. Mald1 native state 440 possess a high internal cavity occupied by water [142] and therefore, pressure may not 441 be able to conform significant hydration changes since the protein is already highly 442 hydrated.

443 HP may have not only an effect on the allergenicity of the food products but can help to 444 increase its digestibility by exposing inaccessible sites of proteins and, thereby, 445 enhancing the efficiency of protein hydrolysis. For example, the time required for 446 proteolysis of $\beta$-lactoglobulin, the major allergen in cow's milk, is reduced from $48 \mathrm{~h}$ to $447 \quad 20 \mathrm{~min}$ at $200 \mathrm{MPa}[143]$.

\subsection{Antiviral vaccines}

450 Several viruses are inactivated or dissociated by pressure. Under pressure, the atomic 451 contacts between subunits are replaced by interactions with the solvent and therefore once pressure is released, viruses cannot come back to their native form. For example,

453 pressure inactivates picornaviruses by causing the lack of VP4 from the intern capsid 454 [144]. Both viruses with polyhedral and helicoidal symmetry are sensitive to pressure. 
455 Even so, not all viruses are equally reactive to pressure, for example, the foot-and456 mouth-disease picanovirus is highly sensitive and poliovirus is much higher resistant 457 against HP[144].

458 Interestingly, virus re-associate under their fusogenic state under pressure, a less 459 infectious and highly immunogenic form[144-146]. This is why high pressure has been 460 suggested for antiviral vaccine development. It has been demonstrated that 461 immunization against HP-inactivated virus is equally effective as against intact virus 462 and have higher immunity response than isolated viral subunits [42,147].

\subsection{Bio-purification}

464 An antigen may be purified from its medium by affinity chromatography due to a steric 465 recognition with an antibody linked to a matrix. The recognition causes an increase in 466 molecular volume and, as pressure causes a volume decrease, it could be useful to apply 467 pressures to dissociate the product of interest without using drastic elution process 468 which reduce the lifetime of matrices [148]. This has been demonstrated for the 469 recovery of $\beta$-galactosidase: four 15 min cycles of $150 \mathrm{MPa}$ at $4{ }^{\circ} \mathrm{C}$ recovers $32 \%$ of $E$.

470 coli $\beta$-galactosidase compared with the $46 \%$ recovered by adding a solution of $\mathrm{pH}=11$ 471 [149]. Although the product yield is lower when using HP, the method is simpler and 472 have a lower impact on matrices than the current elution process.

473 HP ability to disrupt immune complexes has been proved on anti-prostate specific 474 antibody from its antigen [149,150], its dissociation was increased by $22-37 \%$ when 475 pressures from 140 to $550 \mathrm{MPa}$ were applied. Pressure may also optimize the 476 dissociation of amphiphilic biomolecules from a fixed adsorbent: $80 \%$ of Triton-X can 477 be recovered form a bed absorption if a pressure of $250 \mathrm{MPa}$ is applied on the system [151]. 
479 Finally, as pressure can dissociate aggregates, it may be used for the recovery of 480 proteins from inclusion bodies, i.e. aggregates of incomplete folded proteins.

481 Traditionally, to separate proteins from inclusion bodies is necessary to use high

482 concentrations of agents that destroy the spatial structure of proteins with a necessary 483 subsequent difficult refolding. However, a pressure of $240 \mathrm{MPa}$ is effective to dissociate 484 the inclusion bodies of endostatins and a subsequent application of $40 \mathrm{MPa}$ induces the 485 refolding of $78 \%$ of the protein [152].

\subsection{Modulation of Cell Activity}

488 Already relative low applied pressures can enhance the cell activity to our profit, as for 489 example observed at $10 \mathrm{MPa}$ for ethanol production by Saccharomyces cerevisiae [153] 490 which occurs 3 times faster than at atmospheric pressure. Another example is on the 491 fermentation by Clostridium thermocellum [154], this Clostridium converts cellobiose 492 to biofuels and other chemicals but also synthesizes other non-desired products (acetate, $\left.493 \mathrm{H}_{2}, \mathrm{CO}_{2}\right)$. When the fermentation happens under pressure of 7 or $17 \mathrm{MPa}$, the 494 microorganism modifies the metabolic pathways and shifts the production to desired 495 metabolites, reaching an increase of 60 -fold.

496 However, as HP is considered a stress for most cells, it will translate into the expense of 497 additional energy for cell maintenance and growth, reducing the product yield. For 498 example, HP reduces the fermentation rate of lactic acid fermentation due to the 499 inhibitory effect on the growth of Streptococcus thermophilus, Lactobacillus bulgaricus 500 and Bifidobacterium lactis [155]. To avoid the loss of efficiency rates under HP, efforts are made to enhance the resistance to HP of mesophilic microorganisms, leading to HP resistant organisms with higher performance under HP [156]. 
503

504

49 
There are more than 3000 enzymes identified to date and most of them are used for

507 biotechnological applications. Nevertheless, these enzymes are not enough to respond to 508 the new technological challenges that appear each day [157]. One of the problems is the 509 stability of the enzymes under industrial conditions, so it is necessary to find enzymes 510 which are highly resistant to harsh conditions and here deep-sea enzymes may play a 511 major role. Pressure-stable enzymes are capable of sustaining biocatalysis under HP, 512 modifying therefore specific enzymatic reactions, and have even higher thermostability. 513 For example, Biolabs ${ }^{\circledR}$ has already commercialized a DNA polymerase from a 514 hyperthermophile and piezophile Pyrococcus, which presents a half-life of 23 hours at $51595^{\circ} \mathrm{C}$. Moreover, piezophilic enzymes may possess different properties than their 516 surface homologues, which may open new possibilities for industry[158]. The market 517 for industrial enzymes is growing every year and the exploitation of extremozymes is a 518 huge and mostly unexplored resource[159].

519 As we have seen, lipids from extremophiles are unique. Archaea in particular contain 520 lipids which confer to the cell a highly stable and impermeable membrane. The unique 521 stability may be used in biotechnological or pharmaceutical applications, for example to 522 protect therapeutic peptides from the harsh environment of the gastrointestinal 523 tract[160,161]. Additionally, many piezophilic bacteria contain omega 3-PUFAs associated with their cell membrane, which are precursors to hormones and hormone525 like molecules in many animals. Consequently, it could be used for 526 hypertriglyceridemia diseases and clinical studies for this purpose have already been 527 approved[158].

528 The high marine biodiversity has woken up the interest to search new compounds with 529 biopharmaceutical potential[162]. It has been discovered marine derived molecules 
530 with, for example, antitumor potential, for the treatment of pain or antimicrobial 531 activities [158,161,162]. For example, studies have identified some bioactive 532 compounds from marine echinoderms (such as the piezotolerant Cucumaria frondosa) 533 with antiproliferative, antimetastatic and immunomodulatory activities[163].

536 All pressure-specific impacts allow to modify macromolecules and cells in unique ways.

537 Food industry was pioneer in using pressure to inactivate microorganisms and as a 538 pretreatment, but pressure capability does not stop here. Promising applications, such as 539 antiviral vaccines, the use of pressure for bio-purification or to vary cell activities has 540 led to a greater interest on this physical parameter. In addition, piezophile organisms 541 opens a range of possibilities to use pressure-adapted molecules, and to increase, for 542 example, the reaction rates, or to find new active macromolecules. 


\section{Biopharmaceutical}

\section{Bacterial ghosts as delivery systems}

548 Bacterial ghosts are usually obtained by the expression of a lyses gene that leads to the 549 formation of a transmembrane tunnel with its consequent cell material leakage. These 550 products retains their immunogenic properties as their cell surface is not affected. 551 Bacterial ghosts obtained by the expression of lysis gene does not retain their cellular 552 structure and are permeabilized and therefore lose their immunogenic properties. HP is 553 capable to prepare bacterial ghosts without the disadvantages of lysis gene, which $554 \quad$ make them a good option to use as delivery systems for subunit or DNA vaccines. For 555 example, HP bacterial ghosts have been obtained applying a pressure of $100 \mathrm{MPa}$ for 15 min to E.coli.

\section{Cryopreservation}

559 Oocyte cryopreservation by vitrification is one technique used to maintain women's 560 fertility but blastocyst formation rate after this process is still low. This low formation 561 rate is caused by the production of ROS components. As remarked above, sublethal HP 562 stress makes the cells more resistant to thermal treatments and oocytes are not an 563 exception. For example, pig oocytes, mouse and bovine blastocysts show a higher 564 resilience against cryopreservation after being subjected to sublethal hp treatment. 565 Moreover, It has been demonstrated that HP (20-40 MPa for 90-120 min) treated bull 566 and boar spermatozoa before cryopreservation preserve the viability, motility and 567 fertility after thawing.

\section{Vaccines preservation}

HP can be also considered as a stabilizing method for vaccine preservations. It has

571 been demonstrated that high pressure stabilizes attenuated poliovirus against 572 temperatures of $37^{\circ} \mathrm{C}$, giving a higher thermal resistance to this virus. Actual trivalent 573 oral polio vaccine (OPV), as most live vaccines, is heat labile, particularly OPV is 574 between the most heat labile vaccines and it needs to be stored frozen and used 
immediately after thawing. HP treatment may solve the problems of refrigeration guarantying a higher stabilised and effective poliovirus vaccine.

\section{Oncology}

\section{Dendritic cell based vaccines}

Shinitzky and colleagues have been explored the use of HP killed tumor cells as a whole cell vaccine, they have demonstrated that a pressure of 100-200 MPa increases the cell immunogenicity. However, since their phase I study in 2000, there are no more clinical studies using this approach.

Recently, dendritic cell (DC, antigen presenting cells from the mammalian immune system) based vaccines have been studied to obtain a vaccine for tumours. This approach uses pressures of $200-300 \mathrm{MPa}$ to kill cancer cell lines, pressure will reveal immunogenic sites on the killed cancer cell surface. Then, these molecules interacts with the specific receptors presents on the surface of DC and activates the phagocytosis of killed cells by DC. Finally, mature DC will activate tumour cell specific immune responses and therefore it could modify the clinical response of the patient with cancer. Moreover, HP killed cells have easy cryopreservation without affecting their immunogenicity.

This technique is still under development; nevertheless, it is under clinical testings for several cancers indications, such as lung, prostate and ovarian cancers.

\section{Orthopaedics surgery}

The actual treatments for exvivo devitalization of infected or tumour affected bone segments are based on irradiation, autoclaving, thermal treatment or use of chemicals. Even if the devitalization is total using these techniques, they reduce the biomechanical and biological integrity of the bone. The procedure is based on the resection, the extracorporeal disinfection and finally the devitalization before its reimplantation.

High pressure can also be used to exvivo devitalization of bone segments without altering the main proteins present in bone tissue (fibronectine, vitronectine and type I 

collagen). HP inactivates several bacteria, fungi and virus, however it is necessary to take intoaccount that bacteria in bones are less sensitive to HP than in solution.

For example, HP treatment of $300 \mathrm{MPa}$ for $10 \mathrm{~min}$ of a cancerous bone segment is sufficient to inactivate all bone cells, including the bone tumour cells. This possible treatment mainly concerns bone segments and tendons. It has been demonstrated that HP treated Achilles tendons and trabecular bones does not loss their properties after a pressure treatment at $600 \mathrm{MPa}$. Finally, the revitalization of high pressure treated bone segments has been demonstrated indicating that a successful implementation of HP treated bone segments may be possible.

Moreover, HP may be useful to disinfect biomaterials as prosthesis or bone plates and surgical equipment as screws. It has been demonstrated that a pressure of $300 \mathrm{MPa}$ and $40^{\circ} \mathrm{C}$ for 30 min disinfect screws contaminated with Staphylococcus aureus.

\section{Cartilage stimulus}

With the development of tissue engineering, engineered meniscus have been a new option to combat knee cartilage diseases. However, engineered meniscus constructs, without the correct stimulation, possess a lower organization and mechanical properties than the native meniscus.

Cartilage is an avascular and aneural tissue that detects HP, with an adequate stimulation, as a mechanical sign to increase its regeneration. In a normal activity, knee cartilage and synovial joint are hydrostatically pressurized reaching pressures up to $10 \mathrm{MPa}$. For example, it has been demonstrated that static pressure of $5 \mathrm{MPa}$ for $1.5 \mathrm{~h}$ increases the glycosaminoglycan incorporation in explants cultures. Interestingly, the effect of pressure on cartilage differs if the study is done on a chondrocytes monolayer or on a three dimensional matrix, which indicates that the interaction cell extracellular matrix may play a role in HP regulation. 


\section{REFERENCES}

631 [1] Bartlett DH. Microbial Adaptations to the Psychrosphere/Piezosphere. J Molec Microbiol Biotechnol 1999;1:93-100.

[2] Schrenk MO, Huber JA, Edwards KJ. Microbial Provinces in the Subseafloor. Ann Rev Mar Sci 2010;2:279-304. doi:10.1146/annurev-marine-120308-081000.

[3] Hazael R, Meersman F, Ono F, McMillan P. Pressure as a Limiting Factor for

[4] Daniel I, Oger P, Winter R. Origins of life and biochemistry under high-pressure

[6] Kallmeyer J, Pockalny R, Adhikari RR, Smith DC, D’Hondt S. Global distribution of microbial abundance and biomass in subseafloor sediment. Proc Natl Acad Sci 2012;109:16213-6. doi:10.1073/pnas.1203849109.

[7] Oger P, Cario A. La vie sous pression des microorganismes piézophiles. Biol Aujourdhui 2014;208:193-206. doi:10.1051/jbio/2014023.

[8] Simonato F, Campanaro S, Lauro FM, Vezzi A, D’Angelo M, Vitulo N, et al. Piezophilic adaptation: a genomic point of view. J Biotechnol 2006;126:11-25. doi:10.1016/j.jbiotec.2006.03.038.

[9] Demazeau G, Rivalain N. High hydrostatic pressure and biology: A brief history. Appl Microbiol Biotechnol 2011;89:1305-14. doi:10.1007/s00253-010-3070-9. 
[10] Nogi Y, Kato C. Taxonomic studies of extremely barophilic bacteria isolated from the Mariana Trench and description of Moritella yayanosii sp. nov., a new barophilic bacterial isolate. Extremophiles 1999;3:71-7. doi:10.1007/s007920050101.

[11] Kusube M, Kyaw TS, Tanikawa K, Chastain RA, Hardy KM, Cameron J, et al. Colwellia marinimaniae sp. nov., a hyperpiezophilic species isolated from an amphipod within the challenger deep, Mariana Trench. Int J Syst Evol Microbiol 2017;67:824-31. doi:10.1099/ijsem.0.001671.

[12] Birrien JL, Zeng X, Jebbar M, Cambon-Bonavita MA, Quérellou J, Oger P, et al. Pyrococcus yayanosii sp. nov., an obligate piezophilic hyperthermophilic archaeon isolated from a deep-sea hydrothermal vent. Int J Syst Evol Microbiol 2011;61:2827-31. doi:10.1099/ijs.0.024653-0.

[13] Le Chatelier HL. Sur un enoncé général des lois des équilibres chimiques. Comptes-Rendus l'Académie Des Sci 1884;99:786-9.

[14] Mentré P, Hoa GHB. Effects of high hydrostatic pressures on living cells: A consequence of the properties of macromolecules and macromolecule-associated water. Int Rev Cytol 2001;201:1-84. doi:10.1016/S0074-7696(01)01001-4.

[15] Oliveira AC, Gaspar LP, Da Poian AT, Silva JL. Arc repressor will not denature under pressure in the absence of water. J Mol Biol 1994;240:184-7. doi:10.1006/ jmbi.1994.1433.

[16] Rayan G, Macgregor RB. Pressure-induced helix-coil transition of DNA copolymers is linked to water activity. Biophys Chem 2009;144:62-6. doi:10.1016/j.bpc.2009.06.007. 
[17] Silva JL, Oliveira AC, Vieira TCRG, de Oliveira GAP, Suarez MC, Foguel D. High-Pressure Chemical Biology and Biotechnology. Chem Rev 2014;114:723967. doi:10.1021/cr400204z.

[18] Balny C, Masson P, Heremans K. High pressure effects on biological macromolecules: from structural changes to alteration of cellular processes. Biochim Biophys Acta - Protein Struct Mol Enzymol 2002;1595:3-10. doi:10.1016/S0167-4838(01)00331-4.

[19] Balasubramaniam VM (Bala), Martínez-Monteagudo SI, Gupta R. Principles and Application of High Pressure-Based Technologies in the Food Industry. Annu Rev Food Sci Technol 2015;6:435-62. doi:10.1146/annurev-food-022814015539.

[20] Mentré P, Hoa GHB. Effects of high hydrostatic pressures on living cells: A consequence of the properties of macromolecules and macromolecule-associated water 2001;201:1-84. doi:10.1109/ICCASM.2010.5619995.

[21] Rayan G, Macgregor RB. Comparison of the heat- and pressure-induced helixcoil transition of two DNA copolymers. J Phys Chem B 2005;109:15558-65. doi:10.1021/jp050899c.

[22] Takahashi S, Sugimoto N. Effect of pressure on thermal stability of GQuadruplex DNA and double-stranded DNA structures. Molecules 2013;18:13297-319. doi:10.3390/molecules181113297.

[23] Rayan G, Macgregor RB. Pressure-induced helix-coil transition of DNA copolymers is linked to water activity. Biophys Chem 2009;144:62-6. doi:10.1016/J.BPC.2009.06.007. 
[24] Giel-Pietraszuk M, Barciszewski J. A nature of conformational changes of yeast tRNAPhe: High hydrostatic pressure effects. Int J Biol Macromol 2005;37:109_ 14. doi:10.1016/j.ijbiomac.2005.09.003.

[25] Schuabb C, Berghaus M, Rosin C, Winter R. Exploring the free energy and conformational landscape of tRNA at high temperature and pressure. ChemPhysChem 2015;16:138-46. doi:10.1002/cphc.201402676.

[26] Garcia AE, Paschek D. Simulation of the pressure and temperature folding/unfolding equilibrium of a small RNA hairpin. J Am Chem Soc 2008;130:815-7. doi:10.1021/ja074191i.

[27] Takahashi S, Sugimoto N. Pressure-dependent formation of i-motif and Gquadruplex DNA structures. Phys Chem Chem Phys 2015;17:31004-10. doi:10.1039/c5cp04727g.

[28] Heremans K. Biology under extreme conditions. High Press Res 2004;24:57-66. doi:10.1080/08957950310001635828.

[29] Abe F. Exploration of the Effects of High Hydrostatic Pressure on Microbial Growth, Physiology and Survival: Perspectives from Piezophysiology. Biosci Biotechnol Biochem 2007;71:2347-57. doi:10.1271/bbb.70015.

[30] Panick G, Malessa R, Winter R, Rapp G, Frye KJ, Royer CA. Structural characterization of the pressure-denatured state and unfolding/refolding kinetics of staphylococcal nuclease by synchrotron small-angle X-ray scattering and Fourier-transform infrared spectroscopy. J Mol Biol 1998;275:389-402. doi:10.1006/jmbi.1997.1454.

[31] Marion J, Trovaslet M, Martinez N, Masson P, Schweins R, Nachon F, et al. 
Pressure-induced molten globule state of human acetylcholinesterase: Structural and dynamical changes monitored by neutron scattering. Phys Chem Chem Phys 2015;17:3157-63. doi:10.1039/c4cp02992e.

[32] Al-Ayoubi SR, Schummel PH, Golub M, Peters J, Winter R. Influence of cosolvents, self-crowding, temperature and pressure on the sub-nanosecond dynamics and folding stability of lysozyme. Phys Chem Chem Phys 2017;19:14230-7. doi:10.1039/c7cp00705a.

[33] Roche J, Caro JA, Norberto DR, Barthe P, Roumestand C, Schlessman JL, et al. Cavities determine the pressure unfolding of proteins. Proc Natl Acad Sci 2012;109:6945-50. doi:10.1073/pnas.1200915109.

[34] Meersman F, Daniel I, Bartlett DH, Winter R, Hazael R, McMillan PF. HighPressure Biochemistry and Biophysics. Rev Mineral Geochemistry 2013;75:60748. doi:10.2138/rmg.2013.75.19.

[35] Smeller L. Pressure-temperature phase diagrams of biomolecules. Biochim Biophys Acta - Protein Struct Mol Enzymol 2002;1595:11-29. doi:10.1016/S0167-4838(01)00332-6.

[36] Eisenmenger MJ, Reyes-De-Corcuera JI. High pressure enhancement of enzymes: A review. Enzyme Microb Technol 2009;45:331-47. doi:10.1016/j.enzmictec.2009.08.001.

[37] Winter R, Dzwolak W. Exploring the temperature-pressure configurational landscape of biomolecules: from lipid membranes to proteins. Philos Trans Ser A 2005;363:537-63. doi:10.1098/rsta.2004.1507.

[38] Dutra Albuquerque E, Gonçalves Torres FA, Ribeiro Fernandes AA, Fernandes 
PMB. Combined effects of high hydrostatic pressure and specific fungal cellulase improve coconut husk hydrolysis. Process Biochem 2016;51:1767-75. doi:10.1016/j.procbio.2016.07.010.

[39] Huang H-W, Lung H-M, Yang BB, Wang C-Y. Responses of microorganisms to high hydrostatic pressure processing. Food Control 2014;40:250-9. doi:10.1016/J.FOODCONT.2013.12.007.

[40] Gao M, Berghaus M, Möbitz S, Schuabb V, Erwin N, Herzog M, et al. On the Origin of Microtubules’ High-Pressure Sensitivity. Biophys J 2018;114:1080-90. doi:10.1016/j.bpj.2018.01.021.

[41] Girard E, Marchal S, Perez J, Finet S, Kahn R, Fourme R, et al. Structurefunction perturbation and dissociation of tetrameric urate oxidase by high hydrostatic pressure. Biophys J 2010;98:2356-64. doi:10.1016/j.bpj.2010.01.058.

[42] Silva JL, Oliveira AC, Gomes AMO, Lima LMTR, Mohana-Borges R, Pacheco $\mathrm{ABF}$, et al. Pressure induces folding intermediates that are crucial for proteinDNA recognition and virus assembly. Biochim Biophys Acta - Protein Struct Mol Enzymol 2002;1595:250-65. doi:10.1016/S0167-4838(01)00348-X.

[43] Luong TQ, Kapoor S, Winter R. Pressure - A Gateway to Fundamental Insights into Protein Solvation, Dynamics, and Function. ChemPhysChem 2015;16:355571. doi:10.1002/cphc. 201500669.

[44] Librizzi F, Carrotta R, Peters J, Cupane A. The effects of pressure on the energy landscape of proteins. Sci Rep 2018;8:2037. doi:10.1038/s41598-018-20417-x.

[45] Collins MD, Kim CU, Gruner SM. High-Pressure Protein Crystallography and NMR to Explore Protein Conformations. Annu Rev Biophys 2011;40:81-98. 
doi:10.1146/annurev-biophys-042910-155304.

[46] Potekhin SA, Senin AA, Abdurakhmanov NN, Tiktopulo EI. High pressure stabilization of collagen structure. Biochim Biophys Acta - Proteins Proteomics 2009;1794:1151-8. doi:10.1016/j.bbapap.2009.04.005.

[47] Roche J, Ying J, Maltsev AS, Bax A. Impact of Hydrostatic Pressure on an Intrinsically Disordered Protein: A High-Pressure NMR Study of $\alpha$-Synuclein. Chembiochem 2013;14. doi:10.1016/j.den.2011.01.002.The.

[48] Vogel RF, Linke K, Teichert H, Ehrmann MA. High pressure modulated transport and signaling functions of membrane proteins in models and in vivo. $\mathrm{J}$ Phys Conf Ser 2008;121. doi:10.1088/1742-6596/121/11/112005.

[49] Macdonald AG, Martinac B. Effect of high hydrostatic pressure on the bacterial mechanosensitive channel MscS. Eur Biophys J 2005;34:434-41. doi:10.1007/s00249-005-0478-8.

[50] Ulmer HM, Herberhold H, Fahsel S, Gänzle MG, Winter R, Vogel RF. Effects of Pressure-Induced Membrane Phase Transitions on Inactivation of HorA, an ATPDependent Multidrug Resistance Transporter, in Lactobacillus plantarum. Appl Environ Microbiol 2002;68:1088-95. doi:10.1042/CS20150223.

[51] Campanaro S, Vezzi A, Vitulo N, Lauro FM, D’Angelo M, Simonato F, et al. Laterally transferred elements and high pressure adaptation in Photobacterium profundum strains. BMC Genomics 2005;6:1-15. doi:10.1186/1471-2164-6-122.

[52] Powalksa E, Jannosch S, Kinne-Saffran E, Kinne RKH, Fontes CFL, Mignaco JA, et al. Fluorescence Spectroscopic Studies of Pressure and Temperature Effects on $\mathrm{Na}+, \mathrm{K}+$-ATPase Reconstituted into Phospholipid Bilayers and 
Model Raft Mixture Zur Erlangung des akademischen Grades. Biochemistry 2007;46:1672-83.

[53] Periasamy N, Teichert H, Weise K, Vogel RF, Winter R. Effects of temperature and pressure on the lateral organization of model membranes with functionally reconstituted multidrug transporter LmrA. Biochim Biophys Acta - Biomembr 2009;1788:390-401. doi:10.1016/j.bbamem.2008.09.017.

[54] Kapoor S, Triola G, Vetter IR, Waldmann H, Winter R. Revealing conformational substates of lipidated N-ras protein by pressure modulation. Biophys J 2012;102:1468. doi:10.1016/j.bpj.2012.02.038.

[55] Brooks NJ, Ces O, Templer RH, Seddon JM. Pressure effects on lipid membrane structure and dynamics. Chem Phys Lipids 2011;164:89-98. doi:10.1016/j.chemphyslip.2010.12.002.

[56] Matsuki H, Miyazaki E, Sakano F, Tamai N, Kaneshina S. Thermotropic and barotropic phase transitions in bilayer membranes of ether-linked phospholipids with varying alkyl chain lengths. Biochim Biophys Acta - Biomembr 2007;1768:479-89. doi:10.1016/j.bbamem.2006.10.005.

[57] Winter R, Jeworrek C. Effect of pressure on membranes. Phys B Condens Matter 2009;405:2820-6. doi:10.1016/j.physb.2010.04.005.

[58] Trapp M, Marion J, Tehei M, Demé B, Gutberlet T, Peters J. High hydrostatic pressure effects investigated by neutron scattering on lipid multilamellar vesicles. Phys Chem Chem Phys 2013;15:20951-6. doi:10.1039/c3cp52762j.

[59] Ding W, Palaiokostas M, Shahane G, Wang W, Orsi M. Effects of High Pressure on Phospholipid Bilayers. J Phys Chem B 2017;121:9597-606. 
doi:10.1021/acs.jpcb.7b07119.

814

815

816

817

818

819

820

821

822

823

824

825

826

827

828

829

830

831

832

833

[60] McCarthy NLC, Ces O, Law R V., Seddon JM, Brooks NJ. Separation of liquid domains in model membranes induced with high hydrostatic pressure. Chem Commun 2015;51:8675-8. doi:10.1039/c5cc02134k.

[61] Golub M, Lehofer B, Martinez N, Ollivier J, Kohlbrecher J, Prassl R, et al. High hydrostatic pressure specifically affects molecular dynamics and shape of lowdensity lipoprotein particles. Sci Rep 2017;7:46034. doi:10.1038/srep46034.

[62] Lehofer B, Golub M, Kornmueller K, Kriechbaum M, Martinez N, Nagy G, et al. High Hydrostatic Pressure Induces a Lipid Phase Transition and Molecular Rearrangements in Low-Density Lipoprotein Nanoparticles. Part Part Syst Charact 2018;35. doi:10.1002/ppsc.201800149.

[63] Welch TJ, Farewell A, Neighardt FC, Bartlett DH. Stress response in Escherichia coli induced by elevated hydrostatic pressure. J Bacteriol 1993;175:7170-7.

[64] Ludwig H. Effects of High Pressure on Bacteria and Funghi. Adv. High Press. Biosci. Biotechnol. II, 2003, p. 259-65.

[65] Frey B, Franz S, Sheriff A, Korn A, Bluemelhuber G, Gaipl US, et al. Hydrostatic pressure induced death of mammalian cells engages pathways related to apoptosis or necrosis. Cell Mol Biol 2004;50:459-67. doi:10.1170/T534.

[66] Oger PM, Jebbar M. The many ways of coping with pressure. Res Microbiol 2010;161:799-809. doi:10.1016/j.resmic.2010.09.017.

[67] Wuytack EY, Diels AMJ, Michiels CW. Bacterial inactivation by high-pressure homogenisation and high hydrostatic pressure. Int J Food Microbiol 2002;77:205-12. doi:10.1016/S0168-1605(02)00054-5. 
[68] Ritz M, Freulet M, Orange N, Federighi M. Effects of high hydrostatic pressure on membrane proteins of Salmonella typhimurium. Int J Food Microbiol 2000;55:115-9. doi:10.1016/S0168-1605(00)00165-3.

[69] Pagán R, Mackey B. Relationship between membrane damage and cell death in pressure-treated Escherichia coli cells: Differences between exponential- and stationary-phase cells and variation among strains. Appl Environ Microbiol 2000;66:2829-34. doi:10.1128/AEM.66.7.2829-2834.2000.

[70] Patterson MF. Microbiology of pressure-treated foods. J Appl Microbiol 2005;98:1400-9. doi:10.1111/j.1365-2672.2005.02564.x.

[71] Mañas P, Mackey BM. Morphological and Physiological Changes Induced by High Hydrostatic Pressure in Exponential- and Stationary-Phase Cells of Escherichia coli: Relationship with Cell Death. Appl Environ Microbiol 2004;70:1545-54. doi:10.1128/AEM.70.3.1545-1554.2004.

[72] Hill C, Cotter PD, Sleator RD, Gahan CGM. Bacterial stress response in Listeria monocytogenes: Jumping the hurdles imposed by minimal processing. Int Dairy J 2002;12:273-83. doi:10.1016/S0958-6946(01)00125-X.

[73] Black EP, Setlow P, Hocking AD, Stewart CM, Kelly AL, Hoover DG. Response of spores to high-pressure processing. Compr Rev Food Sci Food Saf 2007;6:103-19. doi:10.1111/j.1541-4337.2007.00021.x.

[74] Michiels C, Bartlett DH, Aertsen A. High Pressure Microbiology. vol. ASM Press. 2008.

[75] Wang CY, Huang HW, Hsu CP, Yang BB. Recent Advances in Food Processing Using High Hydrostatic Pressure Technology. Crit Rev Food Sci Nutr 
2016;56:527-40. doi:10.1080/10408398.2012.745479.

860

861

862

863

864

865

866

867

868

869

870

871

872

[76] Jorgensen BB, D’Hondt S. A Starving Majority Deep Beneath the Seafloor. Science (80- ) 2006;314:932-4. doi:10.1126/science.1133796.

[77] Howe A. Deep-sea hydrothermal vent fauna: evolution, dispersal, succession and biogeography. Macalester Rev Biogeogr 2009;1:6.

[78] Orcutt BN, LaRowe DE, Biddle JF, Colwell FS, Glazer BT, Reese BK, et al. Microbial activity in the marine deep biosphere: Progress and prospects. Front Microbiol 2013;4:1-15. doi:10.3389/fmicb.2013.00189.

[79] Grassle FJ. Hydrothermal Vent Animals: Distribution and Biology. Science (80- ) 1985;229:713-7.

[80] Kelly RH, Yancey PH. High contents of trimethylamine oxide correlating with depth in deep-sea teleost fishes, skates, and decapod crustaceans. Biol Bull 1999;196:18-25. doi:10.2307/1543162.

[81] Dover CL Van, German CR, Speer KG, Parson LM, Vrijenhoek RC. Evolution and Biogeography of Deep-Sea Vent and Seep Invertebrates. Science (80- ) 2002;295:1253-7. doi:10.1126/science.1067361.

[82] Castellini MA, Castellini JM, Rivera PM. Adaptations to pressure in the RBC metabolism of diving mammals. Comp Biochem Physiol - A Mol Integr Physiol 2001;129:751-7. doi:10.1109/CEIDP.2008.4772920.

[83] Bliznyuk A, Golan H, Grossman Y. Marine Mammals’ NMDA Receptor Structure: Possible Adaptation to High Pressure Environment. Front Physiol 2018;9:1-12. doi:10.3389/fphys.2018.01633.

[84] Fang J, Zhang L, Bazylinski DA. Deep-sea piezosphere and piezophiles : 
geomicrobiology and biogeochemistry. Trends Microbiol 2010;18:413-22. doi:10.1016/j.tim.2010.06.006.

[85] Zhang Y, Li X, Xiao X, Bartlett DH. Current developments in marine microbiology: High-pressure biotechnology and the genetic engineering of piezophiles. Curr Opin Biotechnol 2015;33:157-64. doi:10.1016/j.copbio.2015.02.013.

[86] Bright M, Lallier FH. The biology of vestimentiferan tubeworms. Oceanogr Mar Biol An Annu Rev 2010;48:213-66.

[87] Sobecky PA, Hazen TH. Horizontal Gene Transfer and Mobile Genetic Elements in Marine Systems. vol. 532. 2009. doi:10.1007/978-1-60327-853-9.

[88] van Wolferen M, Ajon M, Driessen AJM, Albers SV. How hyperthermophiles adapt to change their lives: DNA exchange in extreme conditions. Extremophiles 2013;17:545-63. doi:10.1007/s00792-013-0552-6.

[89] Li Z, Li X, Xiao X, Xu J. An integrative genomic island affects the adaptations of the piezophilic hyperthermophilic archaeon Pyrococcus yayanosii to high temperature and high hydrostatic pressure. Front Microbiol 2016;7:1-13. doi:10.3389/fmicb.2016.01927.

[90] Le Fourn C, Brasseur G, Brochier-Armanet C, Pieulle L, Brioukhanov A, Ollivier B, et al. An oxygen reduction chain in the hyperthermophilic anaerobe Thermotoga maritima highlights horizontal gene transfer between Thermococcales and Thermotogales. Environ Microbiol 2011;13:2132-45. doi:10.1111/j.1462-2920.2011.02439.x.

[91] Kurosaka G, Abe F. The YPR153W gene is essential for the pressure tolerance of 
tryptophan permease Tat2 in the yeast Saccharomyces cerevisiae. High Press Res 2018;38:90-8. doi:10.1080/08957959.2017.1413367.

907

[92] Lauro FM, Chastain RA, Blankenship LE, Yayanos AA, Bartlett DH. The unique 16S rRNA genes of piezophiles reflect both phylogeny and adaptation. Appl Environ Microbiol 2007;73:838-45. doi:10.1128/AEM.01726-06.

[93] Bidle KA, Bartlett DH. RecD function is required for high-pressure growth of a deep-sea bacterium. J Bacteriol 1999;181:2330-7.

[94] Abe F, Kato C, Horikoshi K. Pressure-regulated metabolism in microorganisms. Trends Microbiol 1999;7:447-53. doi:10.1016/S0966-842X(99)01608-X.

[95] Li L, Kato C, Nogi Y, Horikoshi K. Distribution of the pressure-regulated operons in deep-sea bacteria. FEMS Microbiol Lett 1998;159:159-66. doi:10.1016/S0378-1097(97)00560-0.

[96] Kitahara R, Sareth S, Yamada H, Ohmae E, Gekko K, Akasaka K. High pressure NMR reveals active-site hinge motion of folate-bound Escherichia coli dihydrofolate reductase. Biochemistry 2000;39:12789-95. doi:10.1021/bi0009993.

[97] Huang Q, Rodgers JM, Hemley RJ, Ichiye T. Extreme biophysics: Enzymes under pressure. J Comput Chem 2017;38:1174-82. doi:10.1002/jcc.24737.

[98] Peters J, Martinez N, Michoud G, Cario A, Franzetti B, Oger P, et al. Deep sea microbes probed by incoherent neutron scattering under high hydrostatic pressure. Zeitschrift Fur Phys Chemie 2014;228:1121-33. doi:10.1515/zpch2014-0547.

[99] Martinez N, Michoud G, Cario A, Ollivier J, Franzetti B, Jebbar M, et al. High 
protein flexibility and reduced hydration water dynamics are key pressure adaptive strategies in prokaryotes. Sci Rep 2016;6:32816. doi:10.1038/srep32816.

[100] Boehr DD, McElheny D, Dyson HJ, Wright PE. Millisecond timescale fluctuations in dihydrofolate reductase are exquisitely sensitive to the bound ligands. Proc Natl Acad Sci 2010;107:1373-8. doi:10.1073/pnas.0914163107.

[101] Bartlett DH, Kato C, Horikoshi K. High pressure influences on gene and protein expression. Res Microbiol 1995;146:697-706. doi:10.1016/0923-2508(96)810667.

[102] Bartlett DH. Pressure effects on in vivo microbial processes. Biochim Biophys Acta 1595 2002;1595:367-81. doi:10.1002/smj.

[103] Feller G. Psychrophilic Enzymes: From Folding to Function and Biotechnology. Scientifica (Cairo) 2013;2013:1-28. doi:10.1155/2013/512840.

[104] Ohmae E, Murakami C, Tate SI, Gekko K, Hata K, Akasaka K, et al. Pressure dependence of activity and stability of dihydrofolate reductases of the deep-sea bacterium Moritella profunda and Escherichia coli. Biochim Biophys Acta Proteins Proteomics 2012;1824:511-9. doi:10.1016/j.bbapap.2012.01.001.

[105] Ichiye T. Enzymes from piezophiles. Semin Cell Dev Biol 2018;84:138-46. doi:10.1016/j.semcdb.2018.01.004.

[106] Sonavane S, Chakrabarti P. Cavities and atomic packing in protein structures and interfaces. PLoS Comput Biol 2008;4. doi:10.1371/journal.pcbi.1000188.

[107] Collins MD, Hummer G, Quillin ML, Matthews BW, Gruner SM. Cooperative water filling of a nonpolar protein cavity observed by high-pressure 

crystallography and simulation. Proc Natl Acad Sci 2005;102:16668-71. doi:10.1073/pnas.0508224102.

[108] Rosenbaum E, Gabel F, Durá MA, Finet S, Cléry-Barraud C, Masson P, et al. Effects of hydrostatic pressure on the quaternary structure and enzymatic activity of a large peptidase complex from Pyrococcus horikoshii. Arch Biochem Biophys 2012;517:104-10. doi:10.1016/j.abb.2011.07.017.

[109] Jebbar M, Franzetti B, Girard E, Oger P. Microbial diversity and adaptation to high hydrostatic pressure in deep-sea hydrothermal vents prokaryotes. Extremophiles 2015;19:721-40. doi:10.1007/s00792-015-0760-3.

[110] Yancey PH, Blake WR, Conley J. Unusual organic osmolytes in deep-sea animals: Adaptations to hydrostatic pressure and other perturbants. Comp Biochem Physiol - A Mol Integr Physiol 2002;133:667-76. doi:10.1016/S10956433(02)00182-4.

[111] Cario A, Jebbar M, Thiel A, Kervarec N, Oger PM. Molecular chaperone accumulation as a function of stress evidences adaptation to high hydrostatic pressure in the piezophilic archaeon Thermococcus barophilus. Sci Rep 2016;6:1-8. doi:10.1038/srep29483.

[112] Brown A, Thatje S. NMDA receptor regulation is involved in the limitation of physiological tolerance to both low temperature and high hydrostatic pressure. Front Mar Sci 2018;5:1-4. doi:10.3389/fmars.2018.00093.

[113] Sinensky M. Homeoviscous Adaptation-A Homeostatic Process that Regulates the Viscosity of Membrane Lipids in Escherichia coli. Proc Natl Acad Sci 1974;71:522-5. doi:10.1073/pnas.71.2.522. 
[114] Van de Vossenberg JLCM, Driessen AJM, Konings WN. The essence of being extremophilic: The role of the unique archaeal membrane lipids. Extremophiles 1998;2:163-70. doi:10.1007/s007920050056.

[115] Oger PM, Cario A. Adaptation of the membrane in Archaea. Biophys Chem 2013;183:42-56. doi:10.1016/j.bpc.2013.06.020.

[116] Siliakus MF, van der Oost J, Kengen SWM. Adaptations of archaeal and bacterial membranes to variations in temperature, $\mathrm{pH}$ and pressure. Extremophiles 2017;21:651-70. doi:10.1007/s00792-017-0939-x.

[117] Usui K, Hiraki T, Kawamoto J, Kurihara T, Nogi Y, Kato C, et al. Eicosapentaenoic acid plays a role in stabilizing dynamic membrane structure in the deep-sea piezophile Shewanella violacea: A study employing high-pressure time-resolved fluorescence anisotropy measurement. Biochim Biophys Acta Biomembr 2012;1818:574-83. doi:10.1016/j.bbamem.2011.10.010.

[118] Myka K, Allcock DJ, Eloe-Fadrosh EA, Tryfona T, Haag AF, Lauro FM, et al. Adaptations of Cold- and Pressure-Loving Bacteria to the Deep-Sea Environment: Cell Envelope and Flagella. Microb Ecol Extrem Environ 2017:1245. doi:10.1007/978-3-319-51686-8.

[119] Kawamoto J, Sato T, Nakasone K, Kato C, Mihara H, Esaki N, et al. Favourable effects of eicosapentaenoic acid on the late step of the cell division in a piezophilic bacterium, Shewanella violacea DSS12, at high-hydrostatic pressures. Environ Microbiol 2011;13:2293-8. doi:10.1111/j.1462-2920.2011.02487.x.

[120] Kaneshiro SM, Clark DS. Pressure Effects on the Composition and ThermalBehavior of Lipids From the Deep-Sea Thermophile Methanococcus-Jannaschii. J Bacteriol 1995;177:3668-72. doi:10.1128/jb.177.13.3668-3672.1995. 
[121] Cario A, Grossi V, Schaeffer P, Oger PM. Membrane homeoviscous adaptation in the piezo-hyperthermophilic archaeon Thermococcus barophilus. Front Microbiol 2015;6:1-12. doi:10.3389/fmicb.2015.01152.

[122] Hradilova N, Sadilkova L, Palata O, Mysikova D, Mrazkova H, Lischke R, et al. Generation of dendritic cell-based vaccine using high hydrostatic pressure for non-small cell lung cancer immunotherapy. PLoS One 2017;12:1-18. doi:10.1371/journal.pone.0171539.

[123] Adkins I, Hradilova N, Palata O, Sadilkova L, Palova-Jelinkova L, Spisek R. High hydrostatic pressure in cancer immunotherapy and biomedicine. Biotechnol Adv 2018;36:577-82. doi:10.1016/j.biotechadv.2018.01.015.

[124] Ferreira E, Mendes YS, Silva JL, Galler R, Oliveira AC, Freire MS, et al. Effects of hydrostatic pressure on the stability and thermostability of poliovirus: A new method for vaccine preservation. Vaccine 2009;27:5332-7. doi:10.1016/j.vaccine.2009.06.099.

[125] Gu R, Feng Y, Guo S, Zhao S, Lu X, Fu J, et al. Improved cryotolerance and developmental competence of human oocytes matured in vitro by transient hydrostatic pressure treatment prior to vitrification. Cryobiology 2017;75:14450. doi:10.1016/j.cryobiol.2016.12.009.

[126] Brouillet M, Gautier H, Miègeville AF, Bouler JM, Merle C, Caillon J. Inactivation of Staphylococcus aureus in calcium phosphate biomaterials via isostatic compression. J Biomed Mater Res - Part B Appl Biomater 2009;91:34853. doi:10.1002/jbm.b.31408.

[127] Huang HW, Wu SJ, Lu JK, Shyu YT, Wang CY. Current status and future trends of high-pressure processing in food industry. Food Control 2017;72:1-8. 
doi:10.1016/j.foodcont.2016.07.019.

1023

1024

1025

1026

1027

1028

1029

1030

1031

1032

1033

1034

1035

1036

1037

1038

1039

1040

1041

1042

1043

1044

[128] Farkas DF, Hoover DG. High pressure processing. J Food Sci 2000;65:47-64.

[129] Polydera AC, Stoforos NG, Taoukis PS. Comparative shelf life study and vitamin $\mathrm{C}$ loss kinetics in pasteurised and high pressure processed reconstituted orange juice. J Food Eng 2003;60:21-9. doi:10.1016/S0260-8774(03)00006-2.

[130] Bull MK, Zerdin K, Howe E, Goicoechea D, Paramanandhan P, Stockman R, et al. The effect of high pressure processing on the microbial, physical and chemical properties of Valencia and Navel orange juice. Innov Food Sci Emerg Technol 2004;5:135-49. doi:10.1016/j.ifset.2003.11.005.

[131] Kaur BP, Kaushik N, Rao PS, Mishra HN. Chilled storage of high pressure processed black tiger shrimp (Penaeus monodon). J Aquat Food Prod Technol 2015;24:283-99. doi:10.1080/10498850.2013.772271.

[132] Evert-Arriagada K, Hernández-Herrero MM, Juan B, Guamis B, Trujillo AJ. Effect of high pressure on fresh cheese shelf-life. J Food Eng 2012;110:248-53. doi:10.1016/j.jfoodeng.2011.05.011.

[133] Sazonova S, Galoburda R, Gramatina I. Application of high-pressure processing for safety and shelf-life quality of meat- a review. 11th Balt Conf Food Sci Technol "FOODBALT 2017" 2017:17-22.

[134] Ananta E, Knorr D. Evidence on the role of protein biosynthesis in the induction of heat tolerance of Lactobacillus rhamnosus GG by pressure pre-treatment. Int $\mathrm{J}$ Food Microbiol 2004;96:307-13. doi:10.1016/j.ijfoodmicro.2004.04.012.

[135] Zhao S, Baik OD, Choi YJ, Kim SM. Pretreatments for the Efficient Extraction of Bioactive Compounds from Plant-Based Biomaterials. Crit Rev Food Sci Nutr 
1046

1047

1048

1049

1050

1051

1052

1053

1054

1055

1056

1057

1058

1059

1060

1061

1062

1063

1064

1065

1066

1067

[136] Vanga SK, Singh A, Raghavan V. Review of conventional and novel food processing methods on food allergens. Crit Rev Food Sci Nutr 2017;57:2077-94. doi:10.1080/10408398.2015.1045965.

[137] Zhou H, Wang C, Ye J, Tao R, Chen H, Li W, et al. Improvement of allergenicity and functional properties of proteins from ginkgo seeds by high hydrostatic pressure treatment. Nongye Gongcheng Xuebao/Transactions Chinese Soc Agric Eng 2016;32:292-8. doi:10.11975/j.issn.1002-6819.2016.08.041.

[138] Kim MY, Lee SH, Jang GY, Park HJ, Li M, Kim S, et al. Effects of high hydrostatic pressure treatment on the enhancement of functional components of germinated rough rice (Oryza sativa L.). Food Chem 2015;166:86-92. doi:10.1016/j.foodchem.2014.05.150.

[139] Peñas E, Gomez R, Frias J, Baeza ML, Vidal-Valverde C. High hydrostatic pressure effects on immunoreactivity and nutritional quality of soybean products. Food Chem 2011;125:423-9. doi:10.1016/j.foodchem.2010.09.023.

[140] Li Y, Yang W, Chung SY, Chen H, Ye M, Teixeira AA, et al. Effect of Pulsed Ultraviolet Light and High Hydrostatic Pressure on the Antigenicity of Almond Protein Extracts. Food Bioprocess Technol 2013;6:431-40. doi:10.1007/s11947011-0666-8.

[141] Houska M, Heroldova M, Vavrova H, Kucera P, Setinova I, Havranova M, et al. Is high-pressure treatment able to modify the allergenicity of the main apple juice allergen, Mal d1? High Press Res 2009;29:14-22.

doi:10.1080/08957950802454068. 
1068

1069

1070

1071

1072

1073

1074

1075

1076

1077

1078

1079

1080

1081

1082

1083

1084

1085

1086

1087

1088

1089

1090

1091

[142] Ahammer L, Grutsch S, Kamenik AS, Liedl KR, Tollinger M. Structure of the Major Apple Allergen Mal d 1. J Agric Food Chem 2017;65:1606-12. doi:10.1021/acs.jafc.6b05752.

[143] Chicón R, Belloque J, Alonso E, Mart N-Lvarez PJ, Pez-Fandi ARL. Hydrolysis under High Hydrostatic Pressure as a Means To Reduce the Binding of $\beta$ Lactoglobulin to Immunoglobulin E from Human Sera. J Food Prot 2008;71:1453-9. doi:10.4315/0362-028X-71.7.1453.

[144] Oliveira AC, Ishimaru D, Gonçalves RB, Smith TJ, Mason P, Sá-Carvalho D, et al. Low temperature and pressure stability of picornaviruses: Implications for virus uncoating. Biophys J 1999;76:1270-9. doi:10.1016/S0006-3495(99)772905.

[145] Silva JL, Foguel D, Poian AT Da, Prevelige PE. The use of hydrostatic pressure as a tool to study viruses and other macromolecular assemblages. Curr Opin Struct Biol 1996;6:166-75. doi:10.1002/aic.690140505.

[146] Dumard CH, Barroso SPC, Santos AC V., Alves NS, Couceiro JNSS, Gomes AMO, et al. Stability of different influenza subtypes: How can high hydrostatic pressure be a useful tool for vaccine development? Biophys Chem 2017;231:116-24. doi:10.1016/j.bpc.2017.04.002.

[147] Silva JL, Luan P, Glaser M, Voss EW, Weber G. Effects of hydrostatic pressure on a membrane-enveloped virus: high immunogenicity of the pressureinactivated virus. J Virol 1992;66:2111-7.

[148] Lemay P. The use of high pressure for separation and production of bioactive molecules. Biochim Biophys Acta - Protein Struct Mol Enzymol 2002;1595:35766. doi:10.1016/S0167-4838(01)00356-9. 
1092

1093

1094

1095

1096

1097

1098

1099

1100

1101

1102

1103

1104

1105

1106

1107

1108

1109

1110

1111

1112

1113

1114

1115

[149] Estevez-Burugorri L, Degraeve P, Espeillac S, Lemay P. High-pressure induced recovery of $\beta$-galactosidases from immunoadsorbents: Stability of antigens and antibodies. Comparison with usual elution procedures. Biotechnol Lett 2000;22:1319-29. doi:10.1023/A:1005659215110.

[150] Cheung CY, Green DJ, Litt GJ, Laugharn JA. High-pressure-mediated dissociation of immune complexes demonstrated in model systems. Clin Chem 1998;44:299-303.

[151] Niemeyer B, Jansen J. An innovative approach for sorptive separation of amphiphilic biomolecules applying high hydrostatic pressure. J Supercrit Fluids 2007;39:354-61. doi:10.1016/j.supflu.2006.03.015.

[152] Chura-Chambi RM, Cordeiro Y, Malavasi N V., Lemke LS, Rodrigues D, Morganti L. An analysis of the factors that affect the dissociation of inclusion bodies and the refolding of endostatin under high pressure. Process Biochem 2013;48:250-9. doi:10.1016/j.procbio.2012.12.017.

[153] Picard A, Daniel I, Montagnac G, Oger P. In situ monitoring by quantitative Raman spectroscopy of alcoholic fermentation by Saccharomyces cerevisiae under high pressure. Extremophiles 2007;11:445-52. doi:10.1007/s00792-0060054-x.

[154] Bothun GD, Knutson BL, Berberich JA, Strobel HJ, Nokes SE. Metabolic selectivity and growth of Clostridium thermocellum in continuous culture under elevated hydrostatic pressure. Appl Microbiol Biotechnol 2004;65:149-57. doi:10.1007/s00253-004-1554-1.

[155] Mota MJ, Lopes RP, Delgadillo I, Saraiva JA. Probiotic yogurt production under high pressure and the possible use of pressure as an on/off switch to stop/start 
fermentation. Process Biochem 2015;50:906-11. doi:10.1016/j.procbio.2015.03.016.

[156] Mota MJ, Lopes RP, Delgadillo I, Saraiva JA. Microorganisms under high pressure - Adaptation, growth and biotechnological potential. Biotechnol Adv 2013;31:1426-34. doi:10.1016/j.biotechadv.2013.06.007.

[157] Dumorné K, Córdova DC, Astorga-Eló M, Renganathan P. Extremozymes: A potential source for industrial applications. J Microbiol Biotechnol 2017;27:649_ 59. doi:10.4014/jmb.1611.11006.

[158] Schroeder G, Bates SS, La Barre S. Bioactive Marine Molecules and Derivatives with Biopharmaceutical Potential. Blue Biotechnol 2018:611-41. doi:10.1002/9783527801718.ch19.

[159] Dalmaso GZL, Ferreira D, Vermelho AB. Marine extremophiles a source of hydrolases for biotechnological applications. Mar Drugs 2015;13:1925-65. doi:10.3390/md13041925.

[160] Benvegnu T, Lemiègre L, Cammas-marion S. New Generation of Liposomes Called Archaeosomes Based on Natural or Synthetic Archaeal Lipids as Innovative Formulations for Drug Delivery. Recent Pat Drug Deliv Formul 2009;33:206-20. doi:10.2174/187221109789105630.

[161] Jacobsen AC, Jensen SM, Fricker G, Brandl M, Treusch AH. Archaeal lipids in oral delivery of therapeutic peptides. Eur J Pharm Sci 2017;108:101-10. doi:10.1016/j.ejps.2016.12.036.

[162] Tortorella E, Tedesco P, Palma Esposito F, January GG, Fani R, Jaspars M, et al. Antibiotics from Deep-Sea Microorganisms: Current Discoveries and 
Perspectives. Mar Drugs 2018;16:1-16. doi:10.3390/md16100355.

1140 [163] Janakiram NB, Mohammed A, Rao C V. Sea cucumbers metabolites as potent anti-cancer agents. Mar Drugs 2015;13:2909-23. doi:10.3390/md13052909.

1142 